\title{
The Industrial Development of Nyasaland
}

\section{Author(s): John Buchanan}

Source: The Geographical Journal, Vol. 1, No. 3 (Mar., 1893), pp. 245-253

Published by: geographicalj

Stable URL: http://www.jstor.org/stable/1773828

Accessed: 12-06-2016 00:31 UTC

\section{Your use of the JSTOR archive indicates your acceptance of the Terms \& Conditions of Use, available at}

http://about.jstor.org/terms

JSTOR is a not-for-profit service that helps scholars, researchers, and students discover, use, and build upon a wide range of content in a trusted digital archive. We use information technology and tools to increase productivity and facilitate new forms of scholarship. For more information about JSTOR, please contact support@jstor.org.

The Royal Geographical Society (with the Institute of British Geographers), Wiley are collaborating with JSTOR to digitize, preserve and extend access to The Geographical Journal 
The principal obstacles therefore occur at Stenka, Kozla to Dojke, Izlasz and Tachtalia, Greben, Jucz, and the Iron Gates, and at each of these points either the channel must be deepened or the difficulty of mounting the rapids diminished, or both, if navigation is to continue without interruption during the season, or, indeed, free of danger at any time. The Roman engineers avoided only the Iron Gates, cutting a canal on the right bank of the Danube through the whole distance. For the other obstructions they trusted to haulage, and constructed a stupendous towing-path, the Trajani Via, parts of which still remain. After the decadence of the Empire, the banks of the Danube became the scene of constant struggles with the Turks, and the question of navigation lost its importance. When the Turks were finally driven out of Hungary and peace restored in the beginning of this century, the Hungarian Council again took the matter up, and in 1816 ordered a survey to be made, which was executed between 1823 and 1838, with much opposition from the Turkish authorities. In 1830, Count Széchenyi attempted actually to begin the work of clearing the river, but in face of the political and engineering difficulties on the right bank thought it best to improve the land communication by constructing a thoroughly good road on the left. The necessary funds having been voted by government Széchenyi commenced operations in 1834, and the road was completed in 1837. The problem of navigation, however, came again into prominence after the Crimean War, and several fresh surveys were made, but without any practical result, until the matter was taken up by the Berlin Congress in 1878 . On July 8th and 13th of that year the Austro-Hungarian government concluded treaties with Servia by which the former undertook to open the Lower Danube, without pecuniary sacrifice on the part of the latter, who were to enjoy full privileges, in consideration of their affording all facilities for the execution of the work; the moneys expended to be recovered, in terms of a former treaty, by tonnage dues. After further delay, caused by financial difficulties, plans based on a final survey were submitted to the Austrian, Servian, and Rumanian governments in 1883 , and a law authorising the undertaking was passed in 1888 , the cost being fixed at nine million florins. Contracts were placed with a syndicate, and signed in May, 1890, and operations formerly inaugurated on September 18th, 1890.

The international work laid upon Hungary at the Berlin Congress closely follows in its main features that of the Roman engineers. Shallows are removed in part by deepening the channel, in part by the erection of dykes, and rapids are overcome not by canals with locks, but by smooth channels and ample towing power. Its completion may be looked for in the end of 1895 .

\section{THE INDUSTRIAL DEVELOPMENT OF NYASALAND.*}

\section{By JOHN BUCHANAN, C.M.G:}

Nyasaland may be said to be situated between $17^{\circ} \mathrm{S}$. and $9^{\circ}$ of $\mathrm{N}$. latitude, and $36^{\circ} \mathrm{E}$. and $33^{\circ} \mathrm{W}$. longitude. It is now reached by the Chindé mouth of the Zambesi. Until the discovery by Mr. Rankin of the Chindé as a navigable river, Nyasaland lay under the great disadvantage of not being accessible save through the territory of a foreign power. We proceed up the Zambesi till we meet the Shiré. This river is followed to the confluence of the Ruo, which, on

* Paper read at the meeting of the British Association at Edinburgh on August 8th, 1892. Reviscd and extended for The Geographical Journal. 
the left bank of the Shiré, furms the British frontier. We may continue to follow the Shiré, depth of water permitting, to Blantyre Port, 10 miles below the Murchison Cataracts, or we may proceed overland from the Ruo to Blantyre or Zomba, and downwards to Lake Nyasa. There is a passable waggon road from Katanga or Blantyre Port, on the Lower Shiré, to Matobe, on the Upper Shire, that is from below to above the Murchison Rapids. At present, however, tsetse fly blocks the upper end of this road to cattle. A road is being constructed by Captain Sclater, R.E., of the British Central Africa Administration, from Chiromo to Lake Nyasa viâ Zomba, and it is by no means chimerical to expect that at least a steam tramway may be in working order on this road within the next five years; greater advances have in the past taken place in Nyasaland within shorter time. Travellers from London to Nyasaland may reach Zomba or Blantyre within seven weeks. Recently I have had letters within five weeks from the date of departure.

Nyasaland is composed of mountain, hill and valley, lake and river, from the ever-present ant-hill to the magnificent Milanje Range, 9000 feet above sea-level, and from the tiny rill trickling forth from secluded spots in the depth of the forest to Nyasa itself, with its 350 miles length of placid blue, peacefully reflecting the unclouded canopy of heaven, or lashing green-crested waves shorewards, shundering and breaking on the beach like the ocean itself. 'The physical aspect of this district may be said to be represented by a series of undulating plateaux, from 2000 to 4000 feet above sea-level, studded with hilis and miniature mountains, clothed to the summit with bush and forest trees, or showing only bald rocks, among which grow euphorbia, and aloe, and tufts of wiry grass, the latter a living exponent of the parable of the sower-exuberant and green while the rain lasts, rapidly passing through a transition stage to sere and lifeless when the supply of moisture fails.

Central Africa has for so long been associated with the idea of barren, arid tracts of waste land that it must be a relief to know that while that description may be true of one or two spots, it is totally inapplicable to the land under consideration. This is a well-watered country. On the mountain sides each ravine has its stream or burn shaded by bracken and bramble.

A prominent feature in the physical aspect of Nyasaland, as in many other parts of Africa, is the grass land which occurs in patches, it may be of acres, or it may be many square miles in extent; these grass lands are known to the natives as "dambo" or "lilambo." They are, as a rule, void of all trees save a species of Eugenia and Protea, and rest, I believe, on an impervious subsoil. During the rainy season the surface soil acts like a sponge, absorbing water till thoroughly saturated, at which stage it becomes virtually a marsh, and the water gravitating to the lowest level forms the nucleus of a stream, or as the natives have it "nduluko." Streams thus formed are, in the cases of some of the larger of these "dambo," almost perennial, but in the majority of cases, drainage and evaporation together exhaust the supply, and the "dambo" in the dry season becomes the driest of the dry places. There are, in addition, on the plateaux depressions large and small, having a great depth of loose soil, acting as a reservoir into which considerable extent of surface and underground drainage gravitates, and forming a nucleus for a perennial stream. These depressions are known to the natives as "litimbi," and form a very important part in the economy of agricultural life. Resting as they usually do on a subsoil of rock or tenacious clay, they have become enormously fertile through the surface-wash of ages having been deposited in them. In certain of them, which I examined by cutting a deep drain, I found that a perpetual ooze existed on the hard subsoil beneath the loose surface soil, the result of this being 
that during the dry season capillary attraction brings to the surface sufficient moisture, which enables the natives to cultivate early crops of maize, beans, pumpkins, etc., while in the rainy season they become veritable sloughs, covered with rank coarse vegetation, into which no man can with safety enter. The drawback to open draining these places is, as proved in my own case, a danger that the surface soil during a deluge of rain slips off the hard under-stratum and is carried away, especially so should the depression be on a slope. On the mountains themselves, for example Milanje and Zomba, at an elevation of 6000 feet above sea-level, we have these depressions, which, as in the case of Zomba during a very wet season, assume the appearance of a small lake. While, therefore, the perennial water supply of Nyasaland comes from mountains and hills, and the streams, in consequence, may be widely separate, we have, owing to these grass lands and depressions, a supplemental supply which very largely benefits the country far on into the dry season, and would be available for the making of dams were the occupancy of the country to demand it.

The rainfall in Nyasaland varies considerably. In the Shire highlands the average is about 52 inches, while on the lake it may average 80 inches or more. During the last ten years, while so far as I know there has been no marked change in the fluvial aspect of the seasons, there has been a decided falling in Lake Nyasa, and a drying up of the Shiré River. At no time within the last sixteen years was the Shiré River so low as in 1891. The Shiré is dependent on Lake Nyasa for its permanent supply, but, what is also of importance is, not that a certain quantity of rain should fall annually, but that the duration of the rainy season should be prolonged.

In 1879, Lake Shirwa was almost completely dried up. Yet notwithstanding, while last dry season was the most severe of any yet experienced by Europeans, there was more water in Lake Shirwa than in 1879. At the north end of Lake Nyasa, old natives will point to a ridge of sand ten or more feet in height above the present level of the lake, and tell you that they remember the water being at that point, while there is undisputed evidence from observations to show that the present average level of the lake is several feet below what it was ten or twelve years ago. Lake Shirwa, which may be looked upon as neither more nor less than a vast flat basin, has receded on the western shore at least a mile within the memory of lads under 25 years of age. Yet there has been no sensible diminution in the rainfall of the eastern Shire Highlands to account for this. At the present moment, meteorological data are of the most meagre kind, but the comparison of a few years' observations, taken in many and varied positions will, I have no doubt, render the problem as to this desiccating influence soluble, and I am sanguine enough to believe that it will be found that the quantity of rainfall is not lessened, but that probably within certain cycles the duration of the rainy season is shortened, and evaporation in consequence does the rest. The cutting down of timber up to date, though bad enough, could have had no serious effect. May not another solution be the gradual rising of this part of the African continent?

The seasons may roughly be divided into four, corresponding to our spring, summer, autumn, and winter. In the end of September, and in the early part of October, notwithstanding the absence of rain, increased - teniperature causes vegetation to revive; trees and shrubs seem able from stores, elaborated during a period of rest, if rest there be, to start forth and carry on almost into full leaf. It is a trying time alike for plants and planter. When only bush and forest are at stake, and Nature can take her own time to repair the damage, the loss may be small; but it is different when fields of coffee are at stake. The best planting months are November and December, and the best growing months December, January, February and March. 
In April, May and June, crops are reaped. June, July and August are the coldest months, when vegetation is outwardly, at least, less active. August sees the great bulk of these trees bare. Few are the non-deciduous trees in Nyasaland, for though by stream and river one sees an evergreen line, it is situation rather than habit that accounts for it.

When I say that Nyasaland is well-wooded, it is not to be understood that we have anything approaching the forests of the Amazons, or the districts recently traversed by Stanley. Ascend hill or mountain and you overlook an apparently densely wooded country, with occasional dark patches of primeval forest, whilst welldefined lines, prominently above the surrounding woodland, indicate the existence of streams or moisture. On close examination this forest proves to be only collectively so; the great bulk of the trees that constitute forest in Nyasaland being from 4 to 12 inches in diameter, and from 8 to 16 feet in height. There are, however, places where this description would not be applicable, and where trees have attained greater size in girth and height, and stand widely apart; the intervening spaces being covered by low scrub and bush. On the plains of both the Lower and Upper Shiré, a marked feature of the landscape is formed by groups of giant acacias and others distinctly separate from one another, fringed by tangled ibriar and straggling thorn, as if Nature had resorted to a picturesque though artificial method of arrangement in adorning what would otherwise be a monotonous plain. The baobab and kigelia are ubiquitous. The acacia, in the struggle for existence, has acquired the property of exclusively establishing itself in deep dark soil, on level plain or mountain slope. Khaya senegalensis, the great canoe tree, "Erythrophloum quinense, the bark of which is used in the poison ordeal, Parkia filicordia, Albrizzia fastigiata, Eugenia cordula, and species of Ficus constitute the leading features of arboreal life by stream-side in the highlands; while species of Pterocarpus, Terminalia, Vitex, Lonchocarpus, Napuca, Brachystegia, preponderate on the undulating plateaux, vast tracts being covered almost exclusively by species of the last-mentioned genera. Recently there has been brought to light a species of conifer of the genus Widdringtonia, found on the top of Milanje at an elevation of 6000 feet. These trees measure in some cases $5 \frac{1}{2}$ feet in diameter, at 6 from their base, with a clear straight stem of 90 feet, the crown attaining to a neight of 160 feet. These arboreal monsters were first brought to our notice by the late Rev. Robert Clelland; the investigation and procuring specimens of them is due to Mr. Alesander Whyte, Naturalist to the British Central Africa Administration, who has already done much, and will doubtless accomplish more in bringing to light hidden objects of scientific interest in Nyasaland. There are already growing in the Residency garden numerous seedlings of this tree; and as the timber is of a valuable nature, efforts will be made to plant it extensively.

From a utilitarian point of view, Nyasaland may be said to be decidedly wanting in timber, though that there are certain available and valuable woods there can be no question. On the lower Shiré and Zambesi a Pterocarpus, a kind of almug, is used largely for boat-building; natural knees of the Kigelia form durable ribs for boats; Eugenia cordata and kindred species we have found to be excellent timber, close-grained, easy to work, and possessing the invaluable quality of lasting well in water, as experienced in a water-wheel at Zomba. It is worthy of notice that this tree is only to be found in wet situations, found often where no other save an imbibing Ficus would survive. Terminalia is also a good wood, short-grained and strong; in Khaya senegalensis, the canoe-tree of Nyasaland, we have a first-class wood, a kind of coarse mahogany. In a species of Bridelia we have a wood almost equal to walnut; in Erythrophlxum!quinense we have a kind of coarse teak almost imperishable. Vitex umbrosa affords a wood light and easily worked, useful for furniture or inside work, where it can be protccted; while the Naxuca kirki, though 


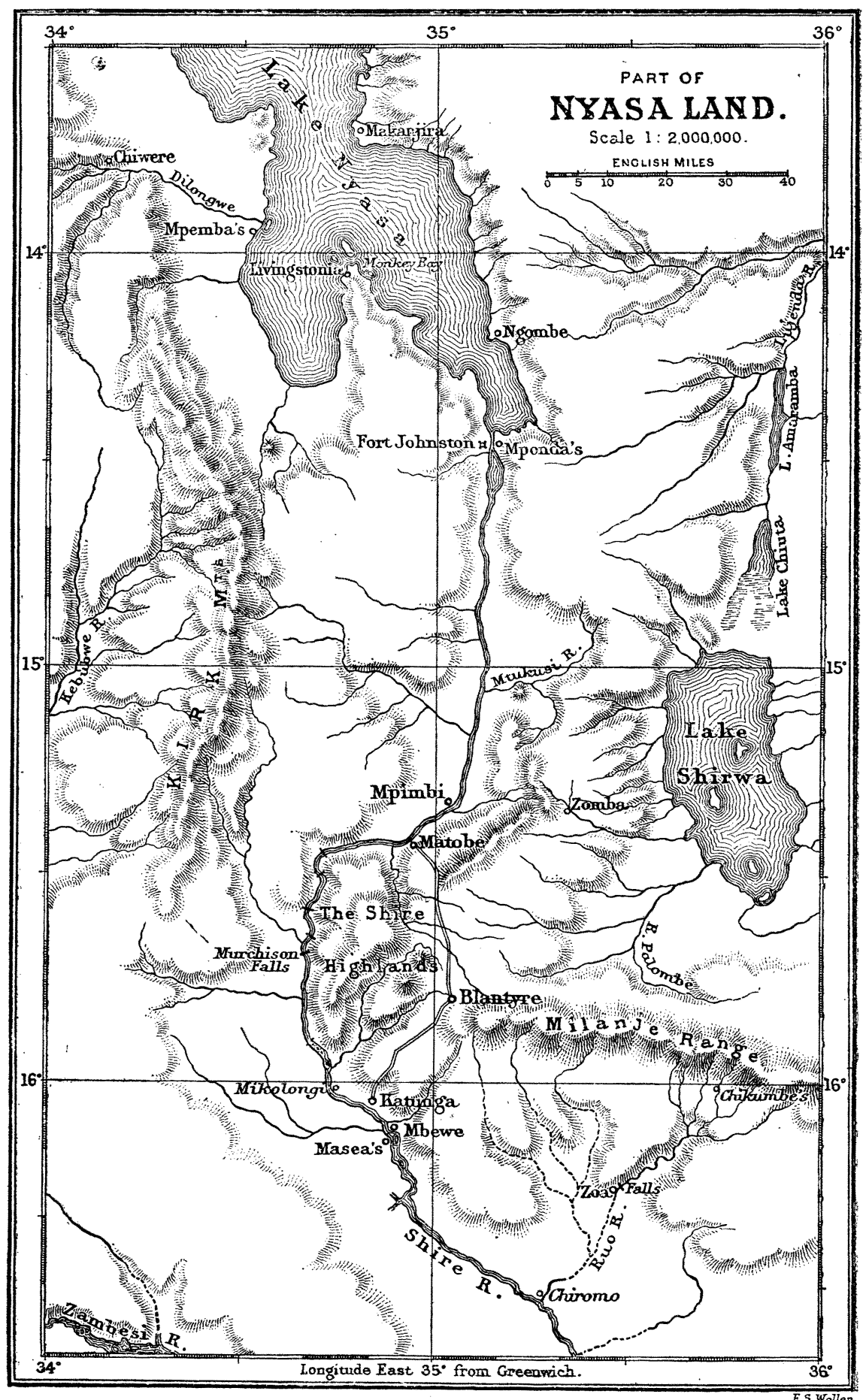


the most common, is perhaps the most useful, certainly the most extensively used wood in the Shiré Highlands. For bridge-building, where durability and great strength are required, Mwenya, a tree resembling a giant larch, with rhododendron-shaped leaves and a wood so dense as to sink to the bottom in water, cannot be beaten. Few are the woods that stand exposure to wind and weather in Africa; fewer still that are proof against the ravages of white ants. We have, however, in Pterocarpus, Bridelia, and Erythrophlæum, specimens possessing this quality. I have seen trunks of the first that have lain on the surface for twenty years in a good state of preservation; while in a species of Louchocarpus, a bastard rosewood, we have a timber that will for years, underground, defy the ravages of termites. The weak point in Nyasaland timber-supply is not that trees are wanting, but that wood of a durable workable quality, obtainable in large quantities, is not to be had. Notwithstanding there being no likelihood of a cubic foot of timber being exported for commercial purposes, we need not take a too pessimistic view of the case; for with better methods of treatment of timber, preservation and conservation of forest, and the amelioration of the present system of native agriculture, whereby, as in the case of Blantyre and Mandala, the country has been virtually devastated, together with a little attention paid by white settlers to reafforesting, timber sufficient to meet internal requirements will always be forthcoming. Already a good deal has been done in the way of introducing blue gum and other trees, and though, in the case of a eucalyptus avenue planted at Zomba, white ants attacked and destroyed the living trees; there is at Blantyre a eucalyptus avenue, planted in 1879, boasting of trees 2 feet in diameter, and close on 100 feet in height, Eucalyptus globulus being the quickest grower.

Passing to the soil, on which a country's wealth so largely depends, Nyasaland possesses a great diversity. In the Shiré and other valleys there are large tracts of alluvial deposit capable of producing enormous crops of grain, rice, sugarcane, oilseeds, cotton, etc., but it is to the undulating table-land and mountainslopes where Europeans can live, and where crops are moderately secure from flooded rivers and excessive moisture, that we must look for the profits of labour. The surface soil of Nyasaland, varying in depth from 4 inches to several feet, greatly diversified in quality, and ranging in colour from a light-blue sand to a jetblack loam, rests generally on a ferruginous clayey subsoil, which again rests upon coarse, rotten granite, affording ample scope for the exercise of skill and agricultural knowledge in the selection of land. Native agriculture, though possessing great interest, must, I fear, be passed over. Suffice it to say that while the devastation of forest is most reprehensible, and the natives themselves cannot give you any reason for their system, they in a sense, practice the essence of agriculture in their methods of maize and sorghum and sweet-potato cultivation, in which ashes and burnt earth play a prominent part, notwithstanding the great waste.

Several of the food-stuffs at present cultivated in Nyasaland are of comparatively recent introduction; and one can trace various food-producing plants already reverted to a wild state that had been cultivated prior to the introduction of maize, cassava, sweet potatoes, etc., and still available, though sadly deteriorated, in seasons of hunger. Crops cultivated by the natives may be summed up in maize, sorghum, rice, millet, beans, sweet-potatoes, yams, bananas, ground-nuts, sem-sem, ginger, turmeric, cotton, hemp, and tobacco; all of which, according to soil and locality, grow freely, and yield abundantly.

We have now to look at our subject from a purely commercial point of view. We have, to start with, in Nyasaland the cardinal elements of commerce. In many parts soil of almost unlimited fertility, abundance of land of average richness, a comparatively healthy climate, natives who, taking them all round, are far 
beyond the average African in point of intelligence and willingness to work, access to the London market, which will improve, and security to life and property afforded by the British Central Africa Administration. I have already stated that grain in the shape of maize, rice, sorghum, beans, etc., can be grown to an unlimited extent; the home demand, however, in an ordinary season, meets the supply, and a high freight nullifies any attempt to grow these grains for export. On the Zambesi a species of wheat is grown which, though not very prolific, produces flour of superior quality, and finds a ready market among the Portuguese and other Europeans on the coast. In the Shire Highlands European wheat has been grown successfully from time to time, though on several occasions rust proved a deadly foe. Sem-sem and ground nuts support a large trade on the Zambesi and Shiré, and are a sure article of export and a greatly extended cultivation of this product on the lowlands may be reasonably anticipated. Flax, too, we found to grow well in ordinarily good soil. Castor-oil plants (Ricinus) are weeds everywhere, there being nearly thirty varieties. The seeds are worth in London about $£ 8$ per ton. Cotton grows on plain and hill. The indigenous variety bas been reported upon as being too short in the staple to be of value as an article of export, its probable use being for the manufacture of candlewick, but we have introduced several leading Egyptian and American varieties, all of which were doing well.

As to fibres, we have species of Sanseviera on hill and plain, which are worth in the London market from $£ 20$ to $£ 40$ per ton. The natives make rope from the Sanseviera longifolia, which they sell to the Europeans. On the shores of Lake Nyasa, and at Cape Maclear in particular, is a bush known as " tingo." This plant, resembling a willow in habits, sends up a number of hazel-like shoots from 2 to 5 feet in length, which, on being cut and the outer bark scraped off, are laid for a few hours in the sun; afterwards the inner bark is removed and manufactured by rubbing and washing, and then spun into twine, the loom being the human limb. Fishing-nets are made of this twine, and resist the action of the water for a considerable period. Nets for the chase are made from the inner bark of the baobab. From the liber of the "njombo," the Brachystegia longifolia, and kindred species, as also from species of Ficus, the native bark cloth is made. The lastnamed, as cloth and cordage enters so largely into the economy of everyday life, that on the lake ficus-trees have become heritable property, while the "njombo" and others, through their accommodating facilities, have so impressed the native mind with the idea of tying, that the verb build has no place in their language, no structure being built but tied. Is it not too much to express the hope that these bark-cloth trees, which have played so prominent a part down the roll of Africa's dark days, may find a still higher use in these advancing times. Both rhea and aloe fibre plants (Fourcroya gigantea) have been introduced and grow luxuriantly. As to rubber, several species of Landolphia are found all over the country, and good prices have been obtained in the London market. The supply, however, is fast disappearing; the native method of collecting is most destructive, and it seems hopeless to educate the natives in this respect owing to their advanced ideas regarding the common rights of property.

I need hardly refer to ivory. Every one has heard of the terrible evils connected with this trade. There must still be great stores of ivory in the interior of Africa. I need not burden this paper by detailing such articles as hides and horns, gums, chillies, ginger, turmeric, etc. These, and others I have mentioned, are marketable, and may become valuable commodities. Much depends upon cheap freight and upon speedy communication with the London market.

But we still want a staple; we want a commercial backbone. No; we are sanguine enough to believe we have found this in coffee. It is now fourteen 
years since, through the kindness of the late Professor Balfour, three coffee plants were presented to the Blantyre Mission. These plants were packed in moss in a flat box, and under the care of $\mathrm{Mr}$. Duncan, who occasionally opened the box and damped the moss, they reached Blantyre after a three months' journey. Two of the three subsequently died, one each of Coffea Arabica and C. Liberica; the other C. Arabica survived, at first grew slowly, but ultimately blossomed forth into flower and fruit. Progress in coffee planting was at first slow, and attended with great risk, the real impetus being given by the declaration of a British Protectorate in 1889. The season of 1892-93 will see about ten million coffee plants planted out in the Shiré Highlands, and this we believe is but the day of small things. Coffee grown by Messrs. Buchanan Bros. at Zomba has fetched a high price in the London market, the feature of the Shiré Highland coffee being a small but compact bean of high flavour. There are of course certain difficulties in the way of coffee extension and successful cultivation, as in everything else. The labour question is already exercising the minds of most planters. We have suffered a good deal from what we might term the "empty-berry-foe"; borer, too, is ever cropping up, but nothing approaching Heniilea vastatrix has been observed.

As I have stated, the coffee at first grown was Coffea Arabica. We have now, however, Blue Mountain and Orange coffee, as also Coffea Liberica. Blue Mountain coffee seems well suited for an elevation of 3000 feet, while the "Orange" coffee, though it bears well at that elevation, is less hardy. Coffea Liberica produces fruit at Blantyre at an elevation of 3300 feet above sea-level, but at that elevation it would not be a profitable crop. Much may be done with it, however, on the lowlands.

Another species, the Coffea Mozambiquensis, is worthy of notice. Presumably indigenous to the country, though so far as I know confined to the sea-level, it has proved itself capable of resisting intense drought at an elevation of over 3000 feet. It has the peculiarity of completely shedding its leaves before coming into flower, it is in fact deciduous. It is a perfectly distinct species both in leaf and fruit and habit of growth. The fruit is very small, but ripens in an incredibly short time.

As to tea, an experiment of 20 acres is being tried at Zomba. Tea has been grown in the Blantyre Mission garden for years, but, considering the present absurdly cheap price of tea, and bearing in view the necessity for having an absolute command of labour for its growth at a time when the natives are most busy with their own gardens, I think it doubtful whether tea will ever rank as a paying product in any part of Central Africa.

Ceara rubber we have introduced, and found it to grow well. There is a great possibility in Ceara rubber, but immediate returns must not be looked for. Notwithstanding the nonsense that has been written as to Ceara requiring only a few stones drawn together, or a hole made with a crowbar and a cutting inserted to ensure success, our Nyasaland experience is, that no plant is more partial to good' soil, nor less likely to repay the planter in a bad one.

Alongside of coffee may be considered cocoa cultivation; the difficulty of securing a supply of plants has been, hitherto, the drawback. This, however, has been overcome, and success is anticipated.

Cinchona may be looked on as an auxiliary. A small parcel of four-year-old bark of so-called Calisaya Verde, grown at Zomba, at an elevation of 3000 fect, realised $4 \mathrm{~d}$. per pound. The following is an analysis of the sample.

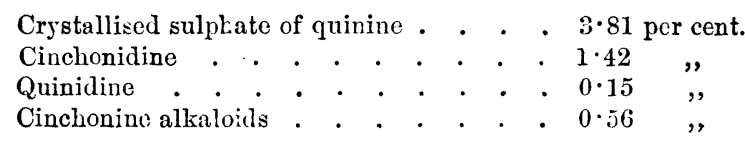


Though the palmy days of cinchona cultivation have long since departed, given land and labour cheap and plentiful, there is yet a great possibility in cinchona to the man who can afford to wait.

Sugar might be cultivated to an unlimited extent on the lowlands. It is grown and manufactured at Zomba for local consumption; but as it is practically a twoyear crop in the highlands, profits from it are small. I have never looked upon sugar as an article of export from Nyasaland, though local demand can always be met.

Tobacco is cultivated by the natives and cured in different ways, and some of this article as manufactured by them is highly prized. From imported seed a finer leafed tobacco has been raised, and a sample of Zomba tobacco was described by a London broker as the finest yet seen from Africa. The native tobacco lies under the disadvantage of being coarse-veined, thick and heavy in every way, totally unsuited for any save the coarsest uses in the home market. Both cut tobacco, cheroots, and cigars, are being manufactured at Zomba for local supply, and, while this is met, planters may look forward to exporting the raw material. A superior tobacco can be cultivated; experience in curing and growing will adapt it to the market.

I feel justified in saying that, commercially, Nyasnland has a bright future before it. We have the backbone of commerce in coffee, cocoa, rubber, tobacco, cotton, cinchona, and it may be, tea, and sugar, and in an already organised trade in oilseeds, capable of unlimited extension, with great probabilities in fibres, grain, hides, beeswax, etc., not to speak of the ivory trade, which will hold its own for several years yet to come.

The development of Nyasaland, considering the circumstances, has been I believe, unique. In June of last year 1891, we entered upon a new régime. It is unnecessary in this place to do more than mention the fact that a Commissioner, in the person of Mr. H. H. Johnston, C.B., sent out by Her Majesty's Government, began to administer the country.

Before concluding, I wish merely to ventilate a railway scheme for British Central Africa which has been in my mind for years. It is simply that we should construct a railway from the Shiré to Lake Nyasa, making Chiromo at the mouth of the Ruo our starting-point, and subsequently another line to connect Nyasa and Tanganyika. For the first project alone a sum of about $£ 500,000$ would be necessary. It seems a large sum, but we may as well look the matter in the face at once, for a few years hence the money will have to be forthcoming.

It needs no prophet to foretell that the lion's share of the work of developing Central Africa, and putting down the slave-trade, has fallen upon Britain's shoulders, and as a nation she can no more shirk her responsibility than can an individual his duty. Central Africa calls aloud for development, and I hold, with pride too, that of all nations on the face of the earth, Britain is the most fit for the work.

\section{THE CONSTRUCTION OF A MAP OF THE WORLD ON A SCALE OF $1: 1,000,000$.}

\section{By Professor Dr. A. PENCK.}

RECENT years have witnessed the accumulation of an enormous mass of geographical information, laid down on maps of a comparatively large scale. We have maps on a scale of $1: 200,000$ (3.15 miles to 1 inch) of nearly all Europe, large tracts of North America, and! portions of Africa and the Indian Empire. 